\title{
Doing it for the kids
}

A few brave postdocs are mixing science with school teaching. Mark Peplow asks them

\section{what they give to, and get from, the children.}

\section{$\mathrm{T}$} he defining moment of Vicky Taylor's postdoc came when she met an eightyear-old girl in a primary school. "I asked her, "What do you think about science?' and she said straight out, 'Men are scientists'," recalls Taylor. "'But I'm a scientist,' I said — and that totally changed her perception."

Taylor, an endocrinologist, is taking part in a scheme that pays researchers at Imperial College London to spend half their time teaching in local schools. INSPIRE (Innovative Scheme for Post-docs in Research and Education), now halfway through its trial period, is a response to fears that science teaching in the United Kingdom is in crisis.

The number of science students in UK schools and universities has fallen in most subjects over the past decade, eroding the supply of science teachers (see graphic). Some 800 new physics teachers were needed in 2000, but only 200 signed up for teacher training. Similar shortages and trends are seen in the United States, and when vacancies are filled, the teachers are less and less likely to have any science training.

INSPIRE is trying to reverse this trend. In collaboration with the pharmaceutical company GlaxoSmithKline, it offers threeyear contracts to postdoctoral researchers, combined with a teacher-training course. Richard Sykes, former chairman of GlaxoSmithKline and current rector of Imperial College, is the driving force behind the scheme, which began in September 2002. Since joining Imperial in 2001, he has become concerned by the shrinking pool of science applicants.

Sykes believes that INSPIRE can shape the next generation of scientists while they are still in the classroom. He had the contacts and clout to bring together drug-industry cash, academic expertise and government support to make it happen. Although INSPIRE's future funding is not yet secure, Sykes believes the scheme could be reproduced in universities and schools around the country.

Why encourage active scientists, not just graduates, to become teachers? Sykes's

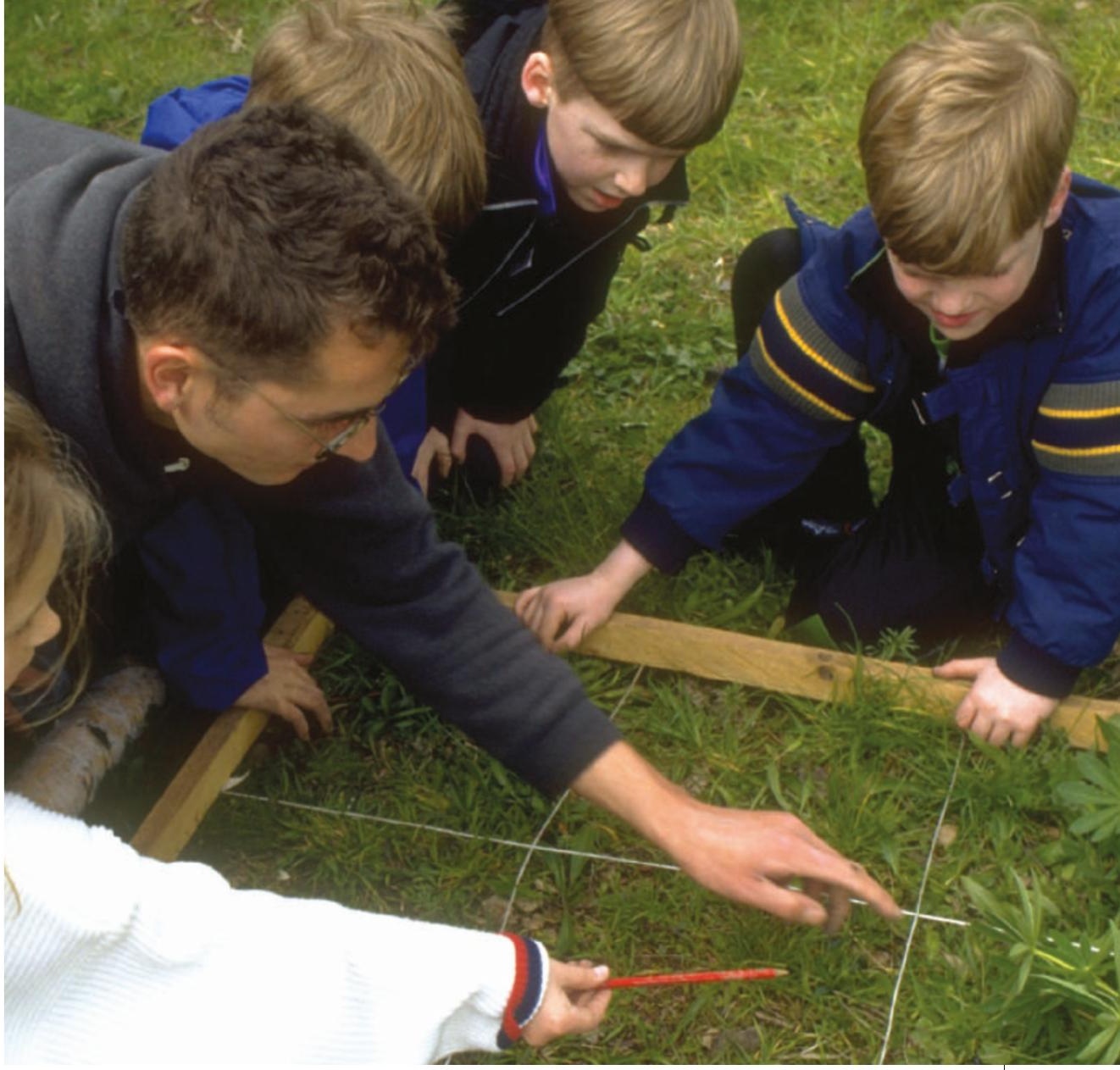

Grass roots: letting in postdocs brings UK schools extra money for science staff and equipment.

response is blunt: "Most people who teach science haven't even been properly educated in it. As kids get older they become more sophisticated and ask more sophisticated questions - and if they don't get answers, they give up." Postdocs have the experience, background and depth of understanding to give them those answers, he claims.

\section{Role models}

John Leach, a professor of science education at the University of Leeds, supports this view. Many science teachers come straight from a degree that was largely about learning facts, he says, with little experience of doing science, either through a $\mathrm{PhD}$ course or industry.

All the INSPIRE postdocs agree that their experience allows them to act as role models, give careers advice, and talk about how science is used in the wider world. But there are some practical benefits too. Jenny Litten is a pig-nutrition researcher at Imperial College's campus in Wye, Kent, and is finishing her first year with INSPIRE. Sometimes the piglets in her research are stillborn, so she dissected one of these animals for a crowd of 60 pupils. The teacher she was working with had a physics background, and would never have done the dissection himself, explains Litten. "It's a different experience for the kids, because not many secondary schools demonstrate dissection any more," she says.

After three years, the INSPIRE postdocs can either continue their research or switch to teaching. None of the original recruits has decided yet. But even if they stay in research, the schools they work in will still have bene-

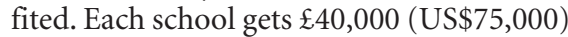
from GlaxoSmithKline to kick-start a bid to become a specialist science college, a move that attracts increased government funding for equipment and staff. The schools spread these benefits by running evening classes, or introducing younger children to science. Taylor's moment with the little girl happened during an outreach visit to a local primary school.

Aisha Rama, a researcher in cardiac medicine, and plant scientist Steven Cook were among the first INSPIRE recruits. Both say that if they become teachers they are more likely to work with older pupils who have chosen to study science. Both saw INSPIRE as a route into teaching that allowed them to continue research projects while earning almost three times as much as trainee teachers.

But juggling two jobs is a challenge. Even though their time should be split evenly between teaching and research, all the postdocs say that studying for a teaching qualification eats into their research time. It is virtually impossible to go to a conference if it happens during a teaching block, says Taylor.

Cook says his research adviser is totally supportive of the scheme, not least because he gets a free 'half-postdoc' for three years. Even though Cook's research has progressed slowly, he believes that having completed 


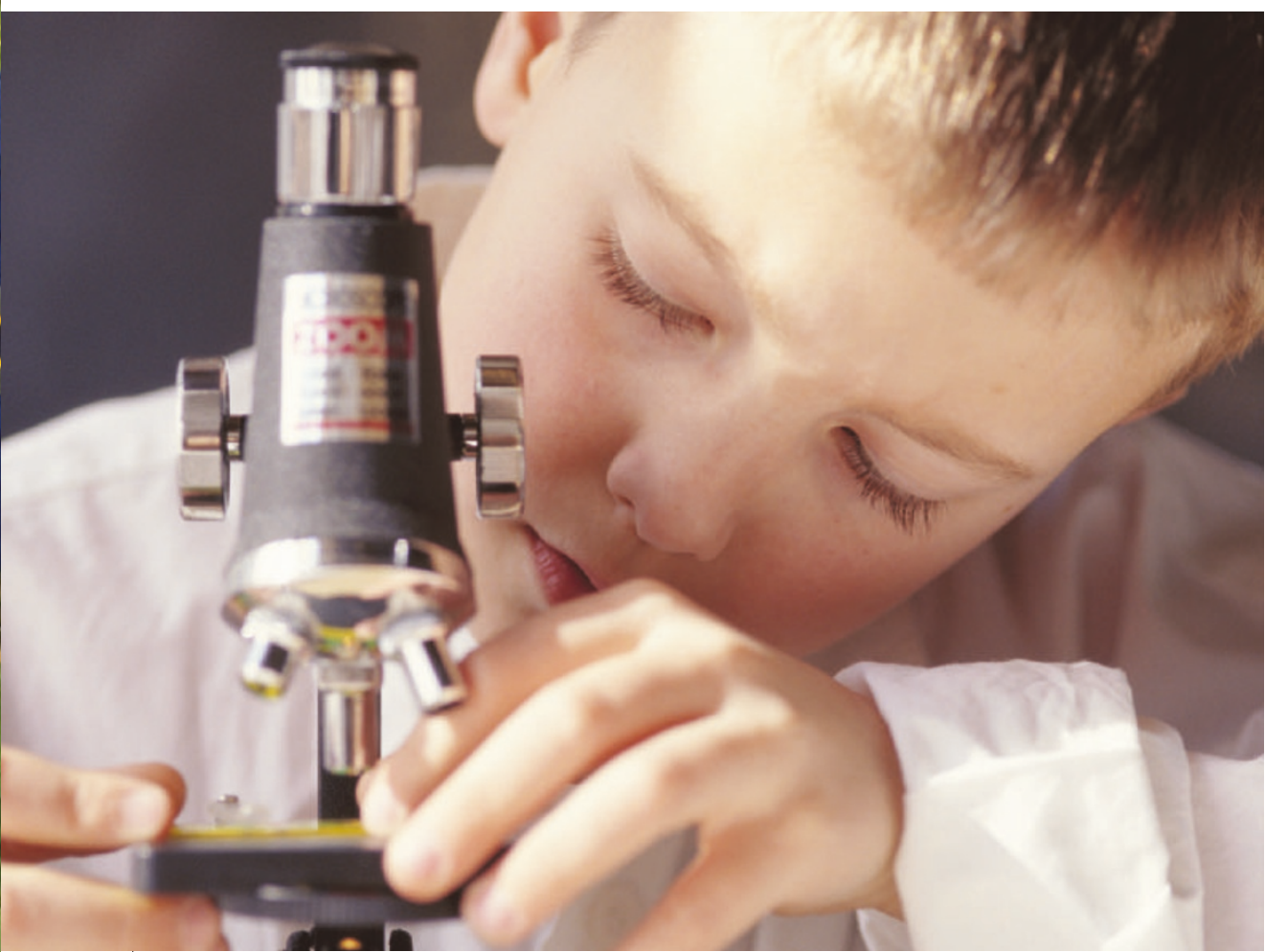

Class act: researchers can make school science lessons more meaningful - and might help reverse the decline in numbers of physics students and teachers (right).

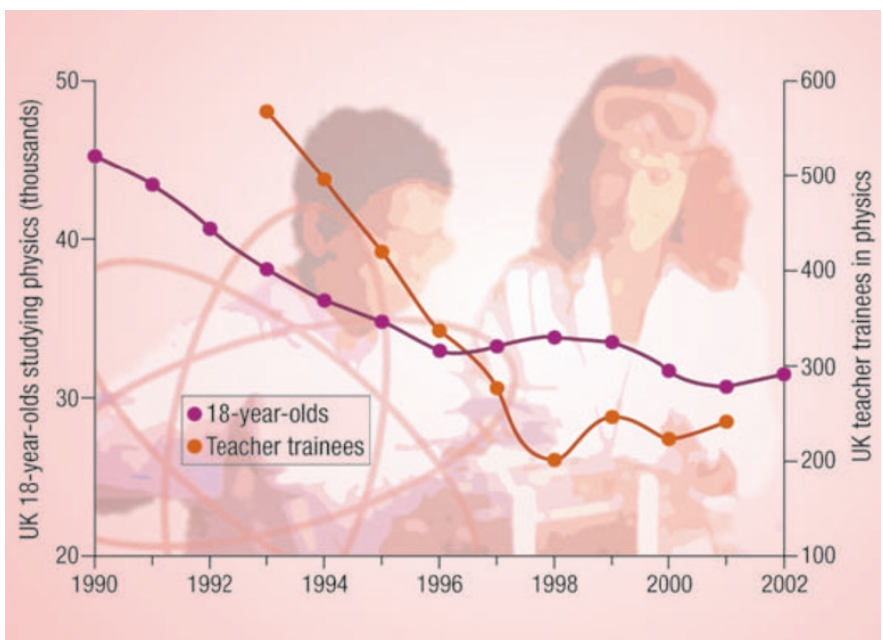

his teacher training he will be able to devote more time to the lab. It is certainly vital to have a supportive lab group: "The team is very adaptable, so the research can continue even when I'm not here," says Litten.

\section{Teacher training}

Some postdocs are attracted to INSPIRE because it offers stability. "It's a guaranteed bit of funding for three years, whereas a lot of postdoc jobs might only be for a year," says David Chestnut, a laser physicist in his first year with INSPIRE. He is undecided about his future, but says that he enjoys teaching and is picking up transferable skills. "It's certainly noticeable in public speaking. I went to a conference a couple of weeks ago where I was much more confident," he says.

Taylor is candid that she saw this as a way to boost her chances of getting a university lectureship. "The one thing I didn't have was a teaching qualification," she says. She points out that the UK government is pushing for all new lecturers to have a formal teaching qualification by 2006. "And if you want to learn teaching skills, it's better to go to where the proper teaching is happening, which is in school," she says. INSPIRE allows her to get a teaching qualification without dropping her research, and gives her an alternative career option that is easier to fit a family around. "It's still a problem for female researchers to take a career break to have kids," she says.

With only six postdoc-teachers so far, can INSPIRE make a real difference? Taylor thinks so: "If you just inspire one Nobel prizewinner then it's been worth it - where would we be if Einstein had opted for English instead of science?" she says. "At first, our interest in INSPIRE was the money," admits Ralph James, head of science at St Gregory's High School in London, where Taylor teaches, but he was surprised by how much difference the postdocs made to practical lessons. "If it's a success then it could be a model to be adopted elsewhere," he adds.

The University of Leeds is launching an equivalent scheme in September. Ceri Nursaw, head of the university's city and regional office, is coordinating the scheme. She hopes that it will yield more applications for Leeds's mathematics and science courses. And, she adds, going into schools is good for researchers: "Teaching will give them a better understanding of their subject." It took Leeds two years to get going, but Nursaw thinks other universities could get a programme started in less than a year.

Shirley Ann Jackson, president of the American Association for the Advancement of Science, has campaigned for similar outreach efforts in the United States for more than two years. She argues that university or industry researchers could make a significant teaching contribution during the school year and focus on their research in the summer. But she says there are as yet no US schemes to foster scientist-teachers.

\section{School's out?}

The key is money: everyone likes these initiatives, but nobody wants to pay for them. After receiving government funding during its first year, INSPIRE's future is looking shaky. Imperial is now funding the postdocs' research themselves, which Sykes says is unsustainable. Despite support from Britain's science minister, David Sainsbury, Sykes says that "the good intentions just get lost in the bureaucratic machine. Kafka had nothing on this." The dual nature of a postdoc's work means that the government departments responsible for research and education each pass the buck, he adds.

Sykes also claims that the research councils that usually fund UK scientists are unwilling to contribute because of the unusual format of the research contracts.

Nor will GlaxoSmithKline guarantee its involvement beyond the trial period. "Who knows where we'll be in two years time?" says Katie Pinnock, the company's director of UK corporate contributions. But Imperial plans to hire more INSPIRE postdocs over the next two years, says Sykes, and support them until the end of their contracts.

There won't be a shortage of applicants. In its first year, the scheme attracted more than 50 applications from Imperial for just three positions. All six postdocs say that they would recommend the scheme to anyone interested in teaching, and the schools remain keen. "The students have really warmed to the fact that these people are actually using science for something useful," says Gareth Cross, a teacher at Stewards School in Harlow, Essex, and one of the science teachers involved. "And on top of that, they can bring a little bit of awe and wonder into the classroom."

Mark Peplow is a reporter for Nature's online news team. 